\title{
Dentification of Economic Behavior of Aspects of Consumption in the "Banjarnese" River Culture as a Supplient of Teaching Materials in the Middle School
}

\author{
Maulida $^{1 *}$ Dwi Atmono ${ }^{1}$ M. Rahmattullah ${ }^{1}$ \\ ${ }^{I}$ Economic Education Study Program, Faculty of Teacher Training and Education, University of Lambung Mangkurat, \\ Indonesia \\ "Corresponding author. E-mail:maulidamaul26@gmail.com
}

\begin{abstract}
The river is a natural resource that has a versatile function for human life, one of its functions is for consumption activities. This study aims to identify consumption behavior that shows the culture of the banjar river. This study uses qualitative phenomenology, and data analysis uses the Spreadley (Ethnographic) model with 24 respondents. The results showed the age of children using the river for secondary needs, namely as a means of recreation. Productive and non-productive ages utilize rivers for secondary needs (bathing and washing). In its use is as a substitute item. The difference in the use of rivers past and present is that of the past, rivers are used to meet primary needs (cooking and drinking), whereas now the river is only used as a secondary need because the inclusion of PDAM water makes it easier for the community.
\end{abstract}

Keywords: Learning Materials, Consumption Behavior, Rivers

\section{INTRODUCTION}

Learning is defined as a process that connects all elements or situations in which human resources are located. According to Slameto[1] that learning is a process in which a person is united by a new behavior change, the result of his own experience in his environment. This process requires learners (teachers), learners (students), and good teaching materials in the form of knowledge, attitudes, skills, arts, religion, and social values. Teaching materials are an important factor in addition to the factors of educators, students, facilities and other components. The interaction between these components is very important in achieving the learning objectives designed by the teacher. Next is Arsanti [2]concluded that teaching materials have a very important role in the effectiveness of learning. In the learning planning process, the teacher is tasked with preparing teaching materials that can support the learning process, so that it can help students achieve optimal learning goals.

The use of teaching materials used by a teacher is very helpful for teachers in achieving learning objectives in each subject. One of the subjects taught in school is economics. According to the Republic of Indonesia Government Regulation No. 19 of 2005 concerning National Education Standards, CHAPTER VII Standard of Facilities and Infrastructure, Article 42 which reads "Every educational unit is required to have facilities which include furniture, educational equipment, educational media, books and other learning resources, consumables, and other necessary equipment. to support an orderly and continuous learning process ". Furthermore, in the 2013 Curriculum there is environment-based learning, namely,
Economic learning is defined as a part of social science that teaches human behavior in meeting daily needs and in decision making. One of the economic subjects in schools is to learn about consumption activities. Consumption activity is one of the human activities in order to fulfill needs. According to Suhardi[3]Consumption is defined as human activity by using or using goods and services to meet needs. The purpose of a person to consume is to meet their needs. Everyone's consumption behavior is different. The diversity of consumer behavior occurs because it is influenced by various factors.

According to Kotler (1997) the main factors that influence consumer behavior are cultural factors, social factors, personal factors and psychological factors [4]. This is in line with research conducted by Yakin [5]which concluded that cultural factors, social factors, personal factors, and psychological factors have a positive and significant effect on consumer behavior in shopping for women's clothing at Samarinda Market. Apart from the factors mentioned, there are also other factors that influence consumer behavior such as geographical factors. In general, geographical factors have an effect on consumption patterns as found by Setiyawidi's research [6] which discusses consumer behavior in urban and rural areas which concludes that there are differences in the consideration of types of vegetables between urban and rural consumers.

These studies illustrate that consumer behavior is indeed diverse. The diversity of consumer behavior occurs because it is influenced by many factors, one of which is geographical factors. Banjarmasin as the capital city of South Kalimantan Province is known as the city of a 
thousand rivers because of its geographical conditions which are surrounded by rivers. It is in these circumstances that river life is a prominent feature of this city. In fact, many studies on rivers have been carried out. One of them is the study of rivers in India by Hasink NK [7]. In his research, it was stated that in India the river is a centrifugal and centripetal force, which means that this force can bind the people around it to stay there. Therefore they use the river as part of their life cycle ceremony. From birth to death, rivers play a vital role in people's lives. The river is also considered a commodity because ritual festivals are held there and it is also considered as a symbol of their life from the people who live in and around it.

The same is the case with people in the city of Banjarmasin. The river is used as the heart for the life and livelihood of the surrounding community. Based on the results of interviews with people who live on the banks of the river, currently the role of the river is starting to diminish because the river water has changed unlike before. The problems that make the river change are due to the large amount of household waste or the residue from the results of the production business that pollutes the river and also the current residential structures that are close to the side of the river so that household waste such as residual soap water, human waste, and feces others fall directly into the river. This of course has a huge impact on the quality of river water itself.

Based on the results of interviews with economics subject teachers, it shows that economic subjects have been considered difficult by some students for certain subjects. Even though the teacher thinks that economic learning has been running according to the goals and level of student needs. Obstacles related to economic learning experienced by teachers for material on economic behavior, namely: the difficulty of linking concepts to real conditions in the field so that students are only motivated by the material in the book. The teaching materials used by economics teachers still use worksheets and textbooks as their support Based on these things, the researcher considers that teaching materials based on local wisdom are very important to be applied in schools. The use of the river culture of the urang banjar can be used as a reference for teaching materials in material on the economic behavior of consumption activities. Therefore, the researcher is interested in conducting further research on the consumption behavior of the Banjar river culture as a suplumen of teaching materials in Senior High Schools.

\section{RESEARCH METHOD}

The approach used in this study is a qualitative approach. The type of research used is phenomenological qualitative to describe the economic behavior in the cultural consumption aspects of the urang Banjar river. The subjects in this research are the people on the riverbank of Banjarmasin, who will be taken as informants with the characteristics of their place of residence in the riverside area. The locations taken in this study are: 1) Ketupat Village 2) Sasirangan Village 3) Arab Village 4) South Alalak 5) Basirih and 6) Floating Market.

The data source used is the primary data source, namely the results of interviews with informants regarding consumption activities that reflect the cultural behavior of the urang banjar river. The data analysis technique used is the Spradley model [8] (Ethnography) with taxonomic analysis to determine the relationship of the consumption behavior culture of the river community which is divided into several parts, namely unproductive age, productive age and non-productive age. The validity of qualitative research data in this study used the data credibility test. using triangulation of data collection techniques derived from documentation, interviews and observations.

\section{RESULTS AND DISCUSSION 3.1 Utilization of the River in Consumption Activities}

The description of river consumption behavior that shows the river culture of the banjar people can be seen from various aspects, namely: social aspects, cultural aspects, economic aspects and personal aspects with the categories of children's age, productive age and non-productive age. The social aspect shows that children use the river environment as a place to play and gather with their peers, while the productive age uses the river environment as a place for daily activities and economic activities. The nonproductive age also does the same thing in utilizing the river environment, but this non-productive age also uses the river as a hobby.

The cultural aspect shows that swimming or bathing in the river is one of the hereditary habits practiced by the community. Swimming or bathing in the river is usually done when they are children. This is a hereditary habit carried out from ancient times. Meanwhile, on the personal aspect, it shows the age of the respondents in this study for children aged 10-13 years, productive age ranging from $31-50$ years and non-productive ages ranging from $60-72$ years. The types of needs that are purchased through rivers at productive and non-productive ages are usually the types of production needs for their businesses.

The economic aspect shows that rivers are used for production, distribution and consumption activities. In the perspective of consumption activities, the results of the study show that there are differences in children's ages, productive and non-productive ages in utilizing the river. The following is a summary table of findings from river use in consumption activities. 
Table 1 Summary of Research Findings on River Utilization in Consumption Activities

\begin{tabular}{|c|c|c|c|}
\hline \multicolumn{4}{|c|}{ Subject } \\
\hline $\begin{array}{l}\text { Utilization of the River in } \\
\text { Consumption activities }\end{array}$ & Child Age Period & Productive Age Period & Non Productive Age Period \\
\hline & $\begin{array}{l}\text { The river is used for } \\
\text { consumption activities as } \\
\text { a secondary need, namely } \\
\text { as a recreation area for } \\
\text { children }\end{array}$ & $\begin{array}{l}\text { The river is used in } \\
\text { consumption activities for some } \\
\text { productive respondents as } \\
\text { primary needs and partly as a } \\
\text { substitute when PDAM water is } \\
\text { disrupted }\end{array}$ & $\begin{array}{l}\text { The river is used in } \\
\text { consumption activities for some } \\
\text { non-productive respondents as } \\
\text { primary needs and partly as a } \\
\text { substitute when PDAM water is } \\
\text { disrupted. }\end{array}$ \\
\hline & $\begin{array}{l}\text { Types of activities } \\
\text { carried out in the use of } \\
\text { rivers for consumption } \\
\text { are bathing and fishing }\end{array}$ & $\begin{array}{l}\text { Types of activities carried out } \\
\text { in utilizing the river for } \\
\text { consumption include bathing, } \\
\text { washing clothes, washing } \\
\text { dishes and cleaning floors or } \\
\text { houses }\end{array}$ & $\begin{array}{l}\text { The types of activities carried } \\
\text { out in the use of the river for } \\
\text { consumption are bathing, } \\
\text { washing clothes, washing } \\
\text { dishes, cleaning the land or } \\
\text { houses and looking for fish }\end{array}$ \\
\hline
\end{tabular}

Based on the summary table of findings, it can be illustrated that at the age of children river consumption is used as a secondary need, namely as a place for children's recreation. The productive age in utilizing the river as consumption is used for secondary needs and in its use it is a substitute good. For some non-productive age respondents who do not have PDAM river water, it is used as a secondary need and is the main choice in using water for daily needs such as bathing, washing and defecating. And for some non-productive age respondents who use river PDAM water, it will change its nature to become a substitute item which is used as an alternative choice when PDAM water is experiencing disruption.

This is in accordance with the theory of the life cycle hypothesis put forward by Franco Modigliani in Mankiw [9] explains that "the pattern of public consumption expenditure is based on the fact that the pattern of income and consumption expenditure of a person is generally influenced by the period in his life cycle". Because people tend to receive low income / income at a young age, high at middle age and low at old age. In this study, it can be seen at the age of children whose income is still relatively small and they tend to consume rivers directly. It is different if productive people have a higher income so that the use of rivers for consumption is reduced. Productive people use PDAM water more than rivers. Because they have a bigger income, the consumption used is also higher. In contrast to people who are of non-productive age, their income decreases and river consumption increases. This can be seen from several people who use the river fully for their activities. If he uses PDAM water, the costs paid are greater than using river water, therefore river consumption at non-productive age increases.

\subsection{Description of River Past and Present Utilization}

The description of river use in Banjarmasin is currently experiencing many changes. As stated by Shaleh in Mentayani's research [10]he described that "The river is a major factor in traffic and transportation, the lifeblood of the economy, the route for the spread of culture, the territory of the palace, and also the territory of colonial rule in the $17^{\text {th }}$ to $19^{\text {th }}$ centuries. This long process resulted in the concentration of the population on the riverbanks, namely a relatively higher plain compared to the surrounding area, which is generally still a swamp. And then developed to form a community with its river culture ". This shows that the role of rivers in the city of Banjarmasin in the past can be seen from the river life culture of its people.

Based on the results of interviews with respondents, the quality of river water resources in the city of Banjarmasin is currently experiencing changes. In the past, rivers were used as the main choice in the use of water for consumption needs and also as a support for primary and secondary needs such as cooking, drinking, bathing, washing, and so on. However, now the function of the river has changed due to changes in the quality of river water resources. Rivers are no longer used to support primary needs but are only used as secondary needs such as for bathing, defecating or cleaning household furniture The river's ecosystem and habitat are currently undergoing changes. This can be seen from the reduction in fish and shrimp around residential areas and the almost extinction of other habitats such as sihi and timpakul. In the past, people looked for fish or shrimp only around residential areas, but now the fish and shrimp have moved to places far from their residential areas.

The following is a summary table of research findings on past and present use of rivers in Banjarmasin City. 
Table 2 Utilization of the River Past and Present

\begin{tabular}{|c|l|l|}
\hline $\begin{array}{c}\text { Differences in the Use of the } \\
\text { River Past and Present }\end{array}$ & \multicolumn{1}{|c|}{ Past } & Now \\
\hline River as a necessity & $\begin{array}{l}\text { Using the river as a primary need, } \\
\text { namely for cooking and drinking. In its } \\
\text { use it is used as the main choice }\end{array}$ & $\begin{array}{l}\text { Using the river as a secondary need, namely for } \\
\text { bathing or washing and having the character of a } \\
\text { substitute item, namely as an alternative to use } \\
\text { when PDAM water is disturbed }\end{array}$ \\
\hline Use of the River & $\begin{array}{l}\text { Directly, namely by taking directly from } \\
\text { the river }\end{array}$ & Indirectly assisted by a water pump machine. \\
\hline $\begin{array}{c}\text { Utilization of rivers outside } \\
\text { consumption activities }\end{array}$ & $\begin{array}{l}\text { The river as a transportation route, } \\
\text { including for consumption activities, } \\
\text { namely the purchase of daily necessities } \\
\text { such as vegetables and side dishes, buy it } \\
\text { from the river }\end{array}$ & $\begin{array}{l}\text { The river as a transportation route is only for a } \\
\text { fews needs, such as production needs. And trading } \\
\text { tourist attractions }\end{array}$ \\
\hline River Habitat Life & $\begin{array}{l}\text { The abundance of river habitats such as } \\
\text { fish and shrimp that can be consumed. } \\
\text { And there are also other habitats such as } \\
\text { sihi and timpakul which are now extinct }\end{array}$ & $\begin{array}{l}\text { Fish and shrimp are only in rivers that are far } \\
\text { from residential areas. And other river habitats } \\
\text { that are almost all extinct }\end{array}$ \\
\hline Causative factor & $\begin{array}{l}\text { The amount of household and industrial waste or residue from the production business } \\
\text { - Settlements of residents that are close to the side of the river so that a lot of household } \\
\text { waste pollutes the river }\end{array}$ \\
\hline
\end{tabular}

Source: processed from research data 2019

Based on the summary table of findings, it can be seen that changes in river use in the past and present are influenced by several factors. Meanwhile, the findings from Susmarkanto [11] stated that the behavior of the community and industrialists in disposing of their waste and sewage into rivers is a source/factor causing environmental pollution of river waters, so that rivers experience silting and narrowing which results in further consequences. Based on the results of interviews with respondents, it was stated that changes in the function of the river then and now were caused by the density of the population and settlement structures that were close to the river, some even above the river. This causes household waste such as used washing soap and other feces to pollute river water. And also in an area that has a lot of industrial and production activities, it causes an increase in other wastes from the rest of the production which also pollutes the river.
According to Gusriani [12] Sources of water pollution based on the characteristics of the waste produced can be divided into sources of domestic waste which generally come from residential areas, commercial places (offices, trade and agriculture) and recreational areas. Domestic wastewater mainly consists of feces, urine and wastewater (bathrooms, kitchens, laundry) and non-domestic waste sources originating from activities such as industry or activities that do not originate in residential areas. This waste can come from used washing water, solvents or cooling water from these industries.

\subsection{Research Linkages with the Curriculum}

Based on these findings, if you want to use it as a learning resource, some examples of suitable material and basic competency in learning economics can be seen from the following table.

Table 3 Consumption Behavior that can be used as a source of economic learning

\begin{tabular}{|c|c|c|}
\hline Basic competencies & Learning materials & Consumption Behavior \\
\hline $\begin{array}{l}\text { Grade } 10 \\
\text { KD } 3.3 \\
\text { Analyzing the role of } \\
\text { economic actors in } \\
\text { economic activity }\end{array}$ & $\begin{array}{l}\text { Economic activity } \\
\text { - Consumption (Definition of } \\
\text { consumption, factors that influence } \\
\text { consumption and consumer behavior } \\
\text { theory }\end{array}$ & $\begin{array}{l}\text { 1. Daily activities such as bathing, } \\
\text { washing, defecating, using river water } \\
\text { 2. Hobby activities such as river fishing } \\
\text { 3. Recreational activities such as playing } \\
\text { and swimming in the river }\end{array}$ \\
\hline
\end{tabular}

Source: processed from the results of the 2019 research

\section{CONCLUSION}

Based on the results of research related to the river culture consumption behavior of the Banjar people, several conclusions can be made, namely the Banjar community still uses the river for consumption activities. Consumption activities in utilizing the river are divided into 3 age groups, namely the age of children, productive age, and non-productive age. At the age of children river 
consumption is used as a secondary need, namely as a place for children's recreation. The productive age group uses the river for secondary needs, namely for bathing, defecating, washing and other activities. In its use, rivers are a substitute item, namely as an alternative to use when PDAM water is disturbed. For some non-productive age groups who do not have PDAM river water, it is used as a secondary need and is used as the main choice for daily needs such as bathing, washing and defecating and also used as a satisfying hobby such as fishing. For some nonproductive age respondents who use river PDAM water, it will change into a substitute item which is used as an alternative choice when PDAM water is experiencing disruption There are differences in the use of rivers in the past and the present. drinking, whereas currently rivers are only used as secondary needs because PDAM water has been added to make it easier for the community to use their daily water. In terms of use, In the past, taking river water was done by taking river water directly, whereas now the water extraction is assisted by a water pump machine. The river in the past was also used as a transportation route for all activities including trading and buying and selling activities, whereas now the river transportation route is only used for a few activities, such as distribution activities and trading activities carried out on the river only for tourist attractions. The use of rivers as a consumption activity can be used as a source of supplements for local teaching materials in schools, especially in economic learning regarding Basic Competence 3.3 to analyze the role of economic actors in economic activities on material consumption activities.

\section{SUGGESTION}

Suggestions put forward regarding the findings of this research are: for students, can use the river environment as a learning resource to increase knowledge about the concept of river consumption behavior so that it can facilitate understanding of consumption behavior material in economic learning. And teachers should be able to take advantage of the river environment as a source of student learning that can enrich the knowledge of teachers and students. For other researchers, it is suggested to conduct further studies related to river consumption behavior which shows the river culture of the Banjar people by researching each age group or each aspect in depth. In addition, further studies can also be carried out regarding the use of rivers in other basic competencies that are relevant to research.

\section{REFERENCES}

[1] Slameto, Learning and Influencing Factors. Jakarta: Rineka Cipta, 2015.

[2] M. Arsanti, "The Development of Teaching Materials for Creative Writing Courses with Religious Character Education Values for Students of Pbsi, Fkip, Unissula Study Program," KREDO J. Ilm. Bhs. and Literature, vol. 1, no. 2, pp. 71-90, 2018, doi: $10.24176 /$ credo.v1i2.2107.

[3] Suhardi, Introduction to Microeconomics. Yogyakarta: Media Style, 2016.

[4] D. Kartikasari, "The Influence of Consumer Behavior on Purchasing Decisions," J. Adm. S1 Business Univ. Brawijaya, vol. 3, no. 2, p. 74110, 2013.

[5] M. FAHRUL AINUL YAKIN, "Consumer Behavior in Shopping for Women's Clothing at the Samarinda Morning Market," Economia, vol. 5, no. 3, pp. 298-312, 2016.

[6] R. Setiyawidi and G. Hartono, "Portrait of Vegetable Consumer Behavior in Urban and Rural Areas, the Potrait of Vegetable Consumer 'S Behavior in Urban and Rural Areas," vol. 25, no. 1 , pp. 26-33, 2013.

[7] HNK, "River As a Cultural Construct: Myth and Ritual on the Banks of Bharathappuzha," no. June 2012, p. 12, 2012.

[8] JP Spradley, Ethnographic Method. Yogyakarta: Tiara Wacana, 1979.

[9] NG Mankiw, Macroeconomic Theory. Jakarta: Erlangga, 2003.

[10] I. Mentayani, "IDENTITY AND EXISTENCY OF RIVER EDUCATION IN BANJARMASIN Identity and Existence Riverside Settlement of Banjarmasin," Pros. Semin. Nas. Environment. Wetlands, vol. 4, no. April, pp. 497-502, 2019.

[11] Susmarkanto, "One of the Causes of Floods in Jakarta," J. Technol. Environment., vol. 3, no. pollutants in S Ciliwung, pp. 13-16, 2002.

[12] Y. Gusriani, "Siak Watershed Pollution Control Strategy in Siak Regency," J. Online Mhs. Fak. Science Sos. and Political Science. Univ. Riau, vol. 1, no. 1, pp. 1-13, 2014, [Online]. Available: https://www.n Research.com/publications/31406/strategipengendalian-pencaran-daerah-aliran-sungaidas-siak-di-kabamatan-siak. 